\title{
ELASTIC ANALYSIS OF TWO-STORY OR TWO-BAY DUPLEX FRAMED SHEAR WALLS SUBJECTED TO SYMMETRICAL LOADS WITH RESPECT TO THE AXES OF THE INTERMEDIATE MEMBERS OF THEIR FRAMES
}

\author{
By MASAHIDE TOMII*, MASAFUMI INOUE** \\ and KOSUKE KURIYAMA***
}

Members of A.I.J.

\section{Introduction}

The purpose of this paper is to analyze two-story or two-bay duplex framed shear walls (hereafter referred to as "duplex shear wall"), whose shapes are symmetric with respect to the longitudinal and transversal center lines, to obtain the elastic deformations, plane stresses and two of four partitioned fundamental flexibility matrices from which the stiffness matrix of the duplex shear walls can be derived.

The elastic deformations and stresses of infilled panel walls and frames of the duplex shear walls, which cannot be given by conventional method such as the beam theory and equivalent strut method, can be given by this analysis.

The comparison between the numerical results of the axial force of the column and the vertical displacement of the top of the column of a duplex shear wall by this analysis and those of the conventional equivalent strut method is shown, and the defect of the latter method is pointed out.

The relations between the fundamental flexibility matrices and the stiffness matrix of duplex shear walls were reported by. Tomii and Yamakawa ${ }^{12}$.

This analysis of duplex shear walls is induced from the analysis ${ }^{2), 3)}$ of one-bay-one-story framed shear walls whose edge beams have the same sections but whose edge columns have different sections, where the boundary conditions and analytical method of the left edge column are revised to correspond to the boundary conditions and analytical method of the intermediate beams of the duplex shear walls (See Fig. 1).

This paper deals with the analysis of duplex shear walls subjected to symmetrical loads with respect to the axes of their intermediate beams, where the loads are decomposed into the following two types of fundamental components of plane nodal external forces, moments and distributed loads.

Type II : fundamental components which are symmetric with respect to the longitudinal and transversal center lines of the duplex shear wall

Type III : fundamental components which are antisymmetric with respect to the longitudinal center line of the duplex shear wall and symmetric with respect to the transversal center line of the duplex shear wall

The plane stress analysis of a duplex shear wall assumed to be an isotropic elastic body can be developed by analyzing the quarter part $(x \geqq 0)$ of the duplex shear wall (the half part of a unit shear

* Professor of Structural Engineering, Department of Architecture, Faculty of Engineering, Kyushu University, D. Eng.

** Lecturer of Structural Engineering, Department of Architectural Engineering, Faculty of Engineering, Oita University, M. Eng.

***:* Engineer of Fukuoka Prefecture, M. Eng. 

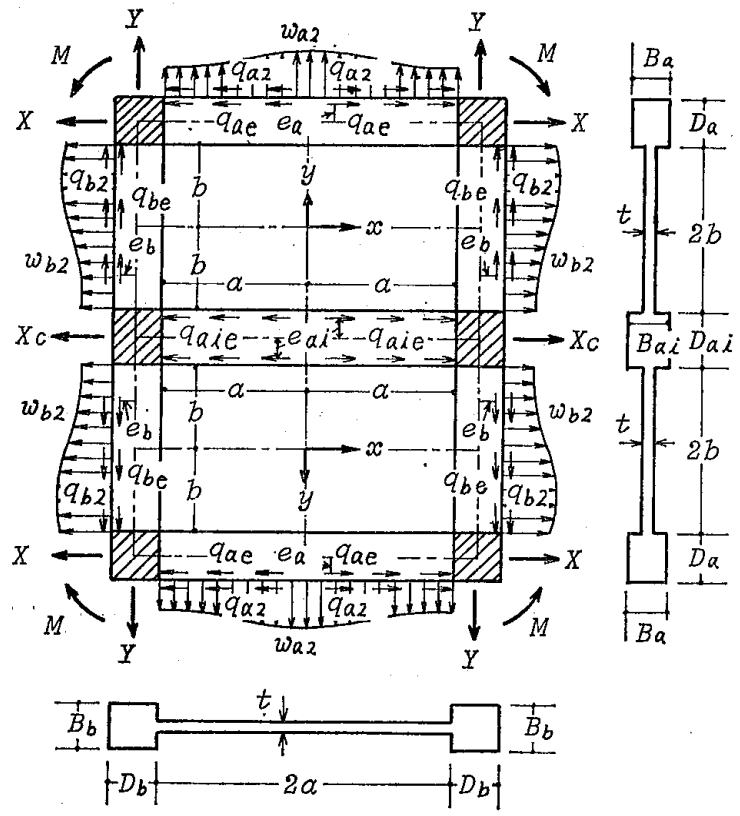

Fundamental components Type II
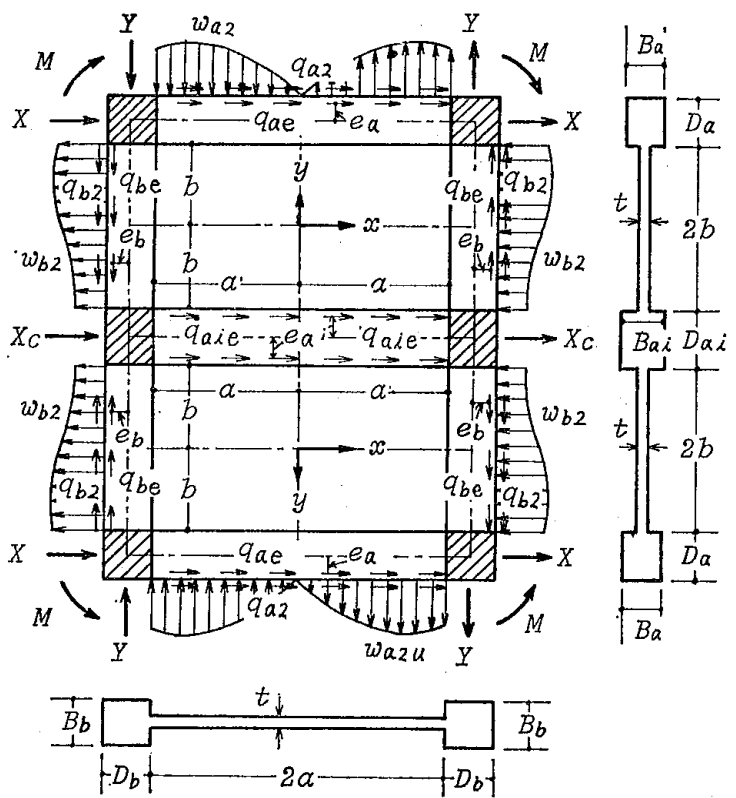

Fundamenta1 compoments Type III

Fig. 1 Examples of the two fundamental components Types II and III of plane nodal external forces, moments and distributed loads

wall) by considering the antisymmetrical and symmetrical loading conditions (See Fig. 1).

The following assumptions are adopted.

1. The coupled infilled panel walls (hereafter referred to as "walls") are two-dimentional elastic bodies.

2. The coupled walls are fixed in the frame.

3. The four connections $D_{a} \times D_{b}$ and the two connections $D_{a i} \times D_{b}$ of the frame are assumed as rigid-zones.

4. Stresses, displacements, etc. in the beams and columns of the frame are derived from the elementary theory of bending, where shearing deformation of the beams and columns is taken into consideration ${ }^{4}$.

Plane nodal external forces, moments and distributed loads of Type II components can be given arbitrarily, but those of Type III components cannot be given arbitrarily and they must satisfy the following equation for equilibrium.

Forces in the $x$ - and $y$-directions and clockwise moments have positive signs (See Fig. 1).

The $\Sigma X=0$ for external forces and distributed loads of Type III components :

$$
X+\frac{1}{2} X_{c}+\int_{0}^{a} q_{a e} d x+\int_{0}^{a} q_{a 2} d x+\int_{0}^{a} q_{a i \theta} d x=\int_{-b}^{b} w_{b 2} d y
$$

\section{Notation}

$a, b \quad=$ Half width and half height of the wall

$A_{a i} \quad=$ Cross sectional area of the intermediate beam

$A_{a m}, B_{a m}, C_{a m}, D_{a m}, A_{a m}^{\prime}, B_{a m}^{\prime}, C_{a m}^{\prime}, D_{a m}^{\prime}, A_{b n}, B_{b n}, C_{b n}, D_{b n}, A_{b n}^{\prime}, B_{b n}^{\prime}, C_{b n}^{\prime}, D_{b n}^{\prime}$

$=$ Unknown coefficients in the serial stress functions

$C_{40}, C_{30}, C_{31}, C_{20}, C_{21}, C_{11}, C_{12}, C_{13}, C_{02}, C_{03}, C_{04}$

$=$ Unknown coefficients in the polynomial stress functions

$D_{a}, D_{a i}, D_{b}=$ Depths of the edge beam, intermediate beam and edge columns

$e_{a}, e_{a i}, e_{b}=$ Eccentric distances (from the center axes of the members) of $q_{a e}, q_{a i e}$ and $q_{b e}$

$E \quad=$ Young's modulus

$F \quad=$ Stress function

$G \quad=$ Shear modulus

$m, n=$ Integers in serial terms 


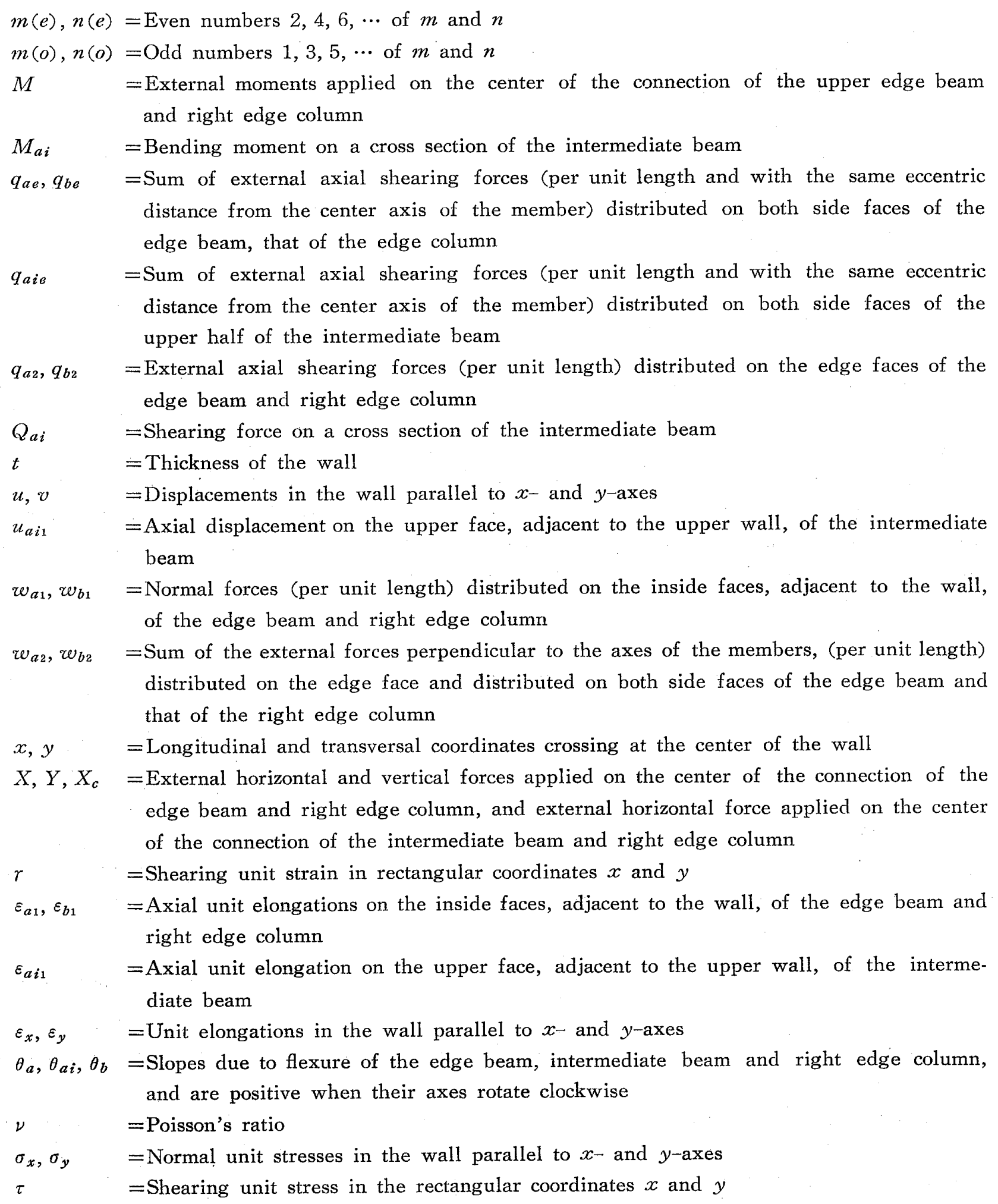

Additional symbols used in this paper are defined where they first appear.

\section{Airy's Stress Functions}

The Airy's stress functions ${ }_{\text {II }} F$ and ${ }_{\text {II }} F$ composed of serial and polynomial functions for Type II and III components are given by Eqs. 2 and 3 .

$$
\begin{aligned}
& \text { ता } F=\sum_{m(a)} \frac{1}{\cosh \alpha_{a m}}\left(A_{a m}^{\prime} \sinh \eta_{m}+B^{\prime}{ }_{a m} \eta_{m} \cosh \eta_{m}+C_{a m} \cosh \eta_{m}+D_{a m} \eta_{m} \sinh \eta_{m}\right) \cos \xi_{m} \\
& +\sum_{n(0)} \frac{1}{\cosh \alpha_{b n}}\left(C_{b n}^{\prime} \cosh \xi_{n}+D_{b n}^{\prime} \xi_{n} \sinh \xi_{n}\right) \sin \eta_{n} \\
& +\sum_{n(e)} \frac{1}{\cosh \alpha_{b n}}\left(C_{b n} \cosh \xi_{n}+D_{b n} \xi_{n} \sinh \xi_{n}\right) \cos \eta_{n} \\
& +\lambda_{b}^{2} C_{40} \xi^{4}+\frac{\lambda_{b}}{2} C_{20} \xi^{2}+C_{21} \xi^{2} \eta-3\left(C_{40}+C_{04}\right) \xi^{2} \eta^{2}+\frac{\lambda_{a}}{2} C_{02} \eta^{2}+C_{03} \eta^{3}+\lambda_{a}{ }^{2} C_{04} \eta^{4}
\end{aligned}
$$




$$
\begin{aligned}
\text { III } F= & \sum_{m(o)} \frac{1}{\cosh \alpha_{a m}}\left(A_{a m} \sinh \eta_{m}+B_{a m} \eta_{m} \cosh \eta_{m}+C_{a m}^{\prime} \cosh \eta_{m}+D_{a m}^{\prime} \eta_{m} \sinh \eta_{m}\right) \sin \xi_{m} \\
& +\sum_{n(o)} \frac{1}{\cosh \alpha_{b n}}\left(A_{b n} \sinh \xi_{n}+B_{b n} \xi_{n} \cosh \xi_{n}\right) \sin \eta_{n} \\
& +\sum_{n(e)} \frac{1}{\cosh \alpha_{b n}}\left(A^{\prime}{ }_{b n} \sinh \xi_{n}+B^{\prime}{ }_{b n} \xi_{n} \cosh \xi_{n}\right) \cos \eta_{n} \\
& +C_{30} \xi^{3}+C_{31} \xi^{3} \eta+C_{11} \xi \eta+C_{12} \xi \eta^{2}+C_{13} \xi \eta^{3} \ldots \ldots \ldots \ldots \ldots \ldots \ldots \ldots \ldots \ldots \ldots \ldots \ldots \ldots \ldots \ldots \ldots \ldots \ldots \ldots \ldots \ldots \ldots \ldots \ldots \ldots \ldots \ldots \ldots \ldots
\end{aligned}
$$

where

$$
\begin{aligned}
& \lambda_{a}=\frac{b}{a}, \quad \alpha_{a m}=\frac{m \pi b}{2 a}, \quad \xi=\frac{x}{a}, \quad \xi_{m}=\frac{m \pi x}{2 a}, \quad \xi_{n}=\frac{n \pi x}{2 b} \\
& \lambda_{b}=\frac{a}{b}, \quad \alpha_{b n}=\frac{n \pi a}{2 b}, \quad \eta=\frac{y}{b}, \quad \eta_{n}=\frac{n \pi y}{2 b}, \quad \eta_{m}=\frac{m \pi y}{2 a}
\end{aligned}
$$

The stress functions if $F$ and ${ }_{\text {III }} F$ satisfy the following compatibility equation.

$$
\frac{\partial^{4} F}{\partial x^{4}}+2 \frac{\partial^{4} F}{\partial x^{2} \partial y^{2}}+\frac{\partial^{4} F}{\partial y^{4}}=0
$$

\section{Unit Stresses, Unit Elongations and Displacements in the Walls}

Normal unit stresses $\sigma_{x}$ and $\sigma_{y}$ parallel to the $x$ - and $y$-axes, respectively, shearing unit stress $\tau$ in the rectangular coordinates $x$ and $y$, unit elongations $\varepsilon_{x}$ and $\varepsilon_{y}$ parallel to the $x$ - and $y$-axes, respectively, shearing unit strain $r$ in the rectangular coordinates $x$ and $y$ and the displacements $u$ and $v$ parallel to the $x$ - and $y$-axes, respectively are given by Eqs. 5 12.

$$
\begin{aligned}
& \sigma_{x}=\frac{\partial^{2} F}{\partial y^{2}} \\
& \sigma_{y}=\frac{\partial^{2} F}{\partial x^{2}} \\
& \tau=-\frac{\partial^{2} F}{\partial x \partial y} \\
& \varepsilon_{x}=\frac{\partial u}{\partial x}=\frac{1}{E}\left(\sigma_{x}-\nu \sigma_{y}\right) \\
& \varepsilon_{y}=\frac{\partial v}{\partial y}=\frac{1}{E}\left(\sigma_{y}-\nu \sigma_{x}\right) \\
& r=\frac{\partial u}{\partial y}+\frac{\partial v}{\partial x}=\frac{\tau}{G}=\frac{2(1+\nu)}{E} \tau \\
& u=\int \frac{\partial u}{\partial x} d x=\frac{1}{E} \int\left(\sigma_{x}-\nu \sigma_{y}\right) d x \\
& v=\int \frac{\partial v}{\partial y} d y=\frac{1}{E} \int\left(\sigma_{y}-\nu \sigma_{x}\right) d y
\end{aligned}
$$

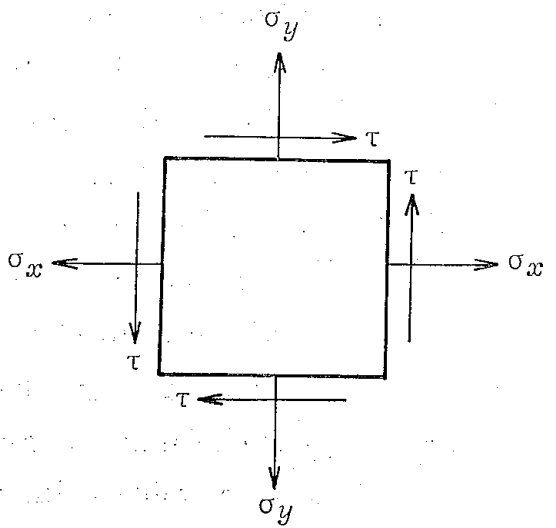

Fig. 2 Unit stresses in the wall

Here, the unit stresses mentioned in Fig. 2 should take the positive sign and $F$ is the stress function given by Eqs. 2 or 3 .

The integration constants in Eqs. 11 and 12 are determined by Eqs. 7, 10, $13 \mathrm{a}, 13 \mathrm{~b}, 14 \mathrm{a}$ and $14 \mathrm{~b}$.

The equations defining the displacements due to the rigid-body motion of duplex shear walls are given by Eqs. $13 \mathrm{a}, 13 \mathrm{~b}, 14 \mathrm{a}$ and $14 \mathrm{~b}$.

For Type II components

$$
\begin{aligned}
& \left.u\right|_{x=0}=0 \\
& \left.v\right|_{y=-b}=0
\end{aligned}
$$

For Type III components

$$
\begin{aligned}
& \left.u\right|_{\substack{x=0 \\
y=0}=0} \\
& \left.v\right|_{y=-b}=0
\end{aligned}
$$

\section{Stresses, Displacements, Etc. in the Beams and Columns of the Frame}

M. Tomii and $H$. Hiraishi reported the equations defining stresses, elongations and displacements in edge beams and edge columns of framed shear walls by considering shearing deformation of the beams and columns ${ }^{4}$. 
These equations can be applied to analyze the edge beams and edge columns of duplex shear walls, but these equations must be revised to analyze the intermediate beams of the duplex shear walls as follows.

The forces and moments on a small segment $D_{a i} \times d x$ of the intermediate beam are shown in Fig. 3.

In the intermediate beam, deflection due to shear, bending moment and shearing force on a

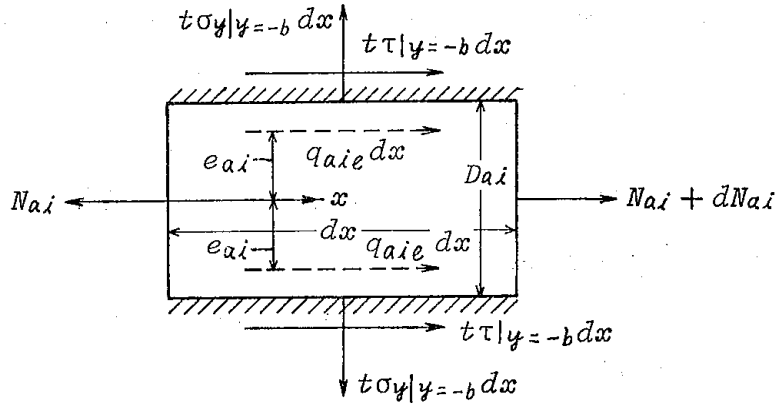

Fig. 3 Forces on a small segment $D_{a i} \times d x$ of the intermediate beam cross section are zero, and axial force $N_{a i}$ on a cross section is given by Eq. 15, and are positive as shown in Fig. 3.

$$
N_{a i}=-\left.2 \int t \tau\right|_{y=-b} d x-2 \int q_{a i e} d x
$$

The $N_{a i}$ caused by Type III components is antisymmetric with respect to the longitudinal center line of duplex shear wall and the integration constant in Eq. 15 is zero. The integration constant for Type II components is set as an unknown factor and can be determined together with other unknown integration constants and coefficients by solving the simultaneous equations for conditions shown in Table 1.

Axial unit elongation $\varepsilon_{a i 1}$ and axial displacement $u_{a i 1}$ on the upper and bottom face, adjacent to the walls, of the intermediate beam are given by. Eqs. 16 and 17 , and $u_{a i_{1}}$ is positive in $x$-direction.

$$
\varepsilon_{a i 1}=\frac{1}{E} \frac{N_{a i}}{A_{a i}}
$$

\begin{tabular}{|c|c|c|c|c|}
\hline \multirow{2}{*}{\multicolumn{2}{|c|}{ The equations }} & \multirow{2}{*}{. } & \multicolumn{2}{|c|}{ The numbers of the equations } \\
\hline & & & Components & Components \\
\hline $\begin{array}{l}\text { Continuity conditions of } \\
\text { normal forces on the } \\
\text { boundary between the wall } \\
\text { and frame }\end{array}$ & $\begin{array}{l}\text { Wal1 - Right edge column } \\
\text { Wa11 - Upper edge beam }\end{array}$ & $\begin{array}{l}t \bar{\sigma}_{x \mid x=a}=\bar{w}_{b 1} \\
t \bar{\sigma}_{\left.y\right|_{y=b}}=\bar{w}_{a 1}\end{array}$ & $\begin{array}{c}{ }_{n}^{n} n(0)+x^{2} n(e)^{+1} \\
r_{m(e)}+1\end{array}$ & $\begin{array}{c}{ }^{2} n(0)+r_{n}(e)+1 \\
n_{n(0)}\end{array}$ \\
\hline $\begin{array}{l}\text { Continuity conditions of } \\
\text { unit elongations on the } \\
\text { boundary between the wall } \\
\text { and frame }\end{array}$ & $\begin{array}{l}\text { Wa11 - Right edge column } \\
\text { Wa11 - Upper edge beam } \\
\text { Wall - Intermediate beam }\end{array}$ & $\begin{aligned} \bar{\varepsilon}_{\left.y\right|_{x=\alpha}} & =\bar{\varepsilon}_{b 1} \\
\bar{\varepsilon}_{x \mid y=b} & =\bar{\varepsilon}_{a 1} \\
\bar{\varepsilon}_{x \mid y=-b} & =\bar{\varepsilon}_{a i 1}\end{aligned}$ & $\begin{array}{c}r_{n(0)}+r_{n(e)}+1 \\
{ }_{m}^{r}(e)+1 \\
r_{m(e)}+1\end{array}$ & $\begin{array}{c}r_{n(0)}+r_{n(e)}+1 \\
r_{m(0)} \\
{ }_{m(0)}\end{array}$ \\
\hline $\begin{array}{l}\text { Continuity condition of } \\
\text { vertical displacement on the } \\
\text { boundary between the wall } \\
\text { and frame }\end{array}$ & Wa11 - Intermediate beam & $\left.v\right|_{y=-b}=0$ & ${ }^{n} m(e)+2$ & ${ }^{r} m(0)^{+2}$ \\
\hline $\begin{array}{l}\text { The equations assuming the } \\
\text { connections to be rigid- } \\
\text { zones }\end{array}$ & $\begin{array}{ll}\text { Right edge } & - \text { Upper edge } \\
\text { column } & \text { beam } \\
\text { Right edge } & - \text { Intermediate } \\
\text { column } & \text { beam }\end{array}$ & $\begin{array}{c}\left.\theta_{b}\right|_{y=b}-\left.\theta_{a}\right|_{x=a}=0 \\
\left.\theta_{a} i\right|_{x=a}=0\end{array}$ & $\begin{array}{l}1 \\
1\end{array}$ & $\begin{array}{l}1 \\
1\end{array}$ \\
\hline $\begin{array}{l}\text { Equilibriums for forces in } \\
\text { the } x \text { and } y \text { directions and } \\
\text { moments on the connections }\end{array}$ & $\begin{array}{l}\text { Right edge }-- \text { Upper edge } \\
\text { colum }\end{array}$ & $\begin{array}{l}\Sigma X=0 \\
\Sigma Y=0 \\
\Sigma M=0\end{array}$ & $\begin{array}{l}1 \\
1 \\
1\end{array}$ & $\begin{array}{l}1 \\
1 \\
1\end{array}$ \\
\hline of the beams and columns & $\begin{array}{l}\begin{array}{l}\text { Right edge }-- \\
\text { column } \\
\text { beam }\end{array} \\
\end{array}$ & $\sum x^{x}=0$ & 1 & 0 \\
\hline $\begin{array}{l}\text { Additional equations : } \\
\left.u\right|_{x=0}=0 \text { (For Type II com }\end{array}$ & nts) & $\begin{array}{l}\text { Total number } \\
\text { of the equations }\end{array}$ & $\begin{array}{r}4 r_{m(e)}+2 r_{n(0)} \\
+2 r_{n(e)}+13\end{array}$ & $\begin{array}{l}{ }^{4 x^{2}} m(0)+2 p^{2} n(0) \\
\quad+2 n_{n(e)}+9\end{array}$ \\
\hline
\end{tabular}

Table 1 The equations defining the unknown coefficients and unknown integration constants

$\left.u\right|_{\substack{x=0 \\ y=0}=0 \text { (For Type III components) }}$

note : the symbol-refers to the Fourier expansion

where

$r_{m(o)}:$ number of $m(o)=1,3,5, \cdots, r_{n(o)}:$ number of $n(o)=1,3,5, \cdots$,

$r_{m(e)}:$ number of $m(e)=2,4,6, \cdots, r_{n(e)}:$ number of $n(c)=2,4,6, \cdots$. 


$$
u_{a i 1}=\int \varepsilon_{a i 1} d x=\frac{1}{E} \int \frac{N_{a i}}{A_{a i}} d x
$$

Deformations caused by Type II components are symmetric with respect to the center of the intermediate beam, and the integration constant in Eq. 17 is zero. The integration constant in Eq. 17 for Type III components is determined by considering the continuity condition $\left.u_{a i 1}\right|_{x=a}=\left.u\right|_{\substack{x=a \\ y=-b}}$, where $\left.u\right|_{\substack{x=a \\ y=-b}}$ is given by Eq. 11 .

\section{Equations for Conditions Defining the Unknown Coefficients and Unknown Integration}

\section{Constants}

The equations for conditions which are necessary to define the unknown coefficients in the stress functions ${ }_{\mathrm{I}} F$ and ${ }_{\mathrm{II}} F$ given by Eqs. 2 and 3 and the unknown integration constants in the derivation processes of the equations are mentioned in Table 1.

The numbers of the simultaneous equations for conditions are $4 r_{m(e)}+2 r_{n(o)}+2 r_{n(e)}+14$ for Type II components and $4 r_{m(o)}+2 r_{n(o)}+2 r_{n(e)}+10$ for Type III components. These numbers are equal to the total numbers of the unknown coefficients in the stress functions ${ }_{\text {II }} F$ and $F$ and the unknown integration constants in the derivation processes of the equations for Type II and III components, respectively. Therefore, the simultaneous equations for Types II and III components can be solved.

\section{Numerical Examples}

The authors deal with the elastic analysis of a duplex shear wall (See Fig. 4) whose unit shear wall has the same definitions as those of a shear wall appearing as a design example in the Commentary of A.I.J. (Architectural Institute of Japan) Building Code Requirements for Reinforced Concrete.

The nodal external forces applied to the duplex shear walls are shown in Fig. 5 and their numerical results of normal stresses $\sigma_{x}$ and $\sigma_{y}$ in the wall, axial force $N$ and bending moment $M$ in the beams and columns of the frame, shearing unit stress $\tau$ in the wall and shearing force $Q$ on a cross section of the beams and columns of the frame are mentioned in Fig. 6 9.

Poisson's ratio $\nu$ is assumed to be $1 / 6$.

The stress distribution of the duplex shear wall subjected to the gravitational loads can be obtained by adding the stress distributions of the duplex shear wall subjected to the vertical nodal components of Type II as shown in Fig. 5 (a) (See Figs. 6 and 7) to the stress distributions of the duplex shear wall subjected to the symmetrical loads with respect to the longitudinal center line of the duplex shear. wall and antisymmetrical loads with respect to the transversal center line of the duplex shear wall $\left(\right.$ Type IV) ${ }^{5}$.

In the case when the duplex shear wall is subjected to the nodal forces of Type III as shown in Fig. 5 (b), which are considered to be one of the main components of external forces during earth-

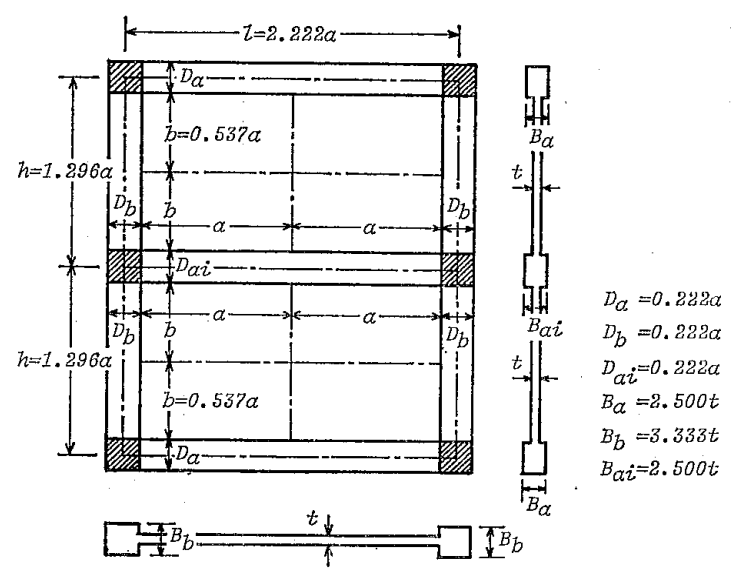

Fig. 4 Definitions of the duplex shear wall adopted as the numerical examples

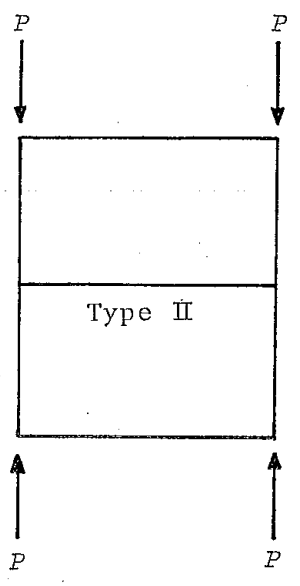

(a)

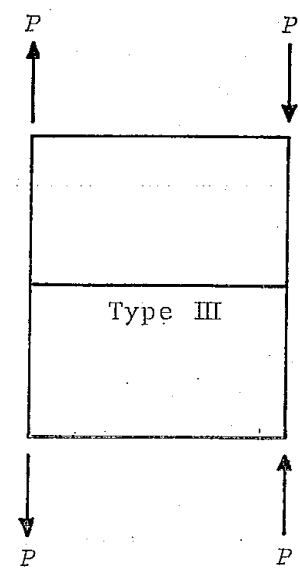

(b)

Fig. 5 The nodal external forces applied to the duplex shear walls adopted as the numerical examples 


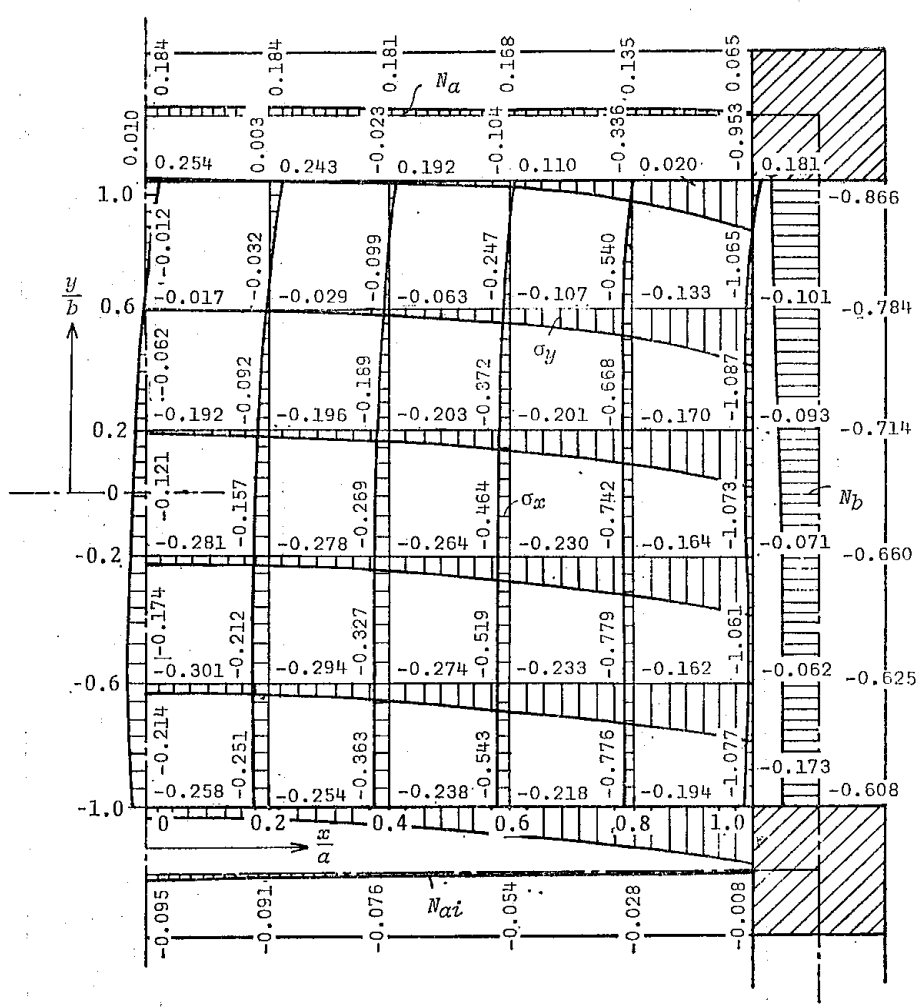

Fig. 6 The normal stresses $\sigma_{x}$ and $\sigma_{y}$ in the wall (unit: $P / t h$ ) and the axial force $N$ in the frame (unit: $P$ ) [Type II]

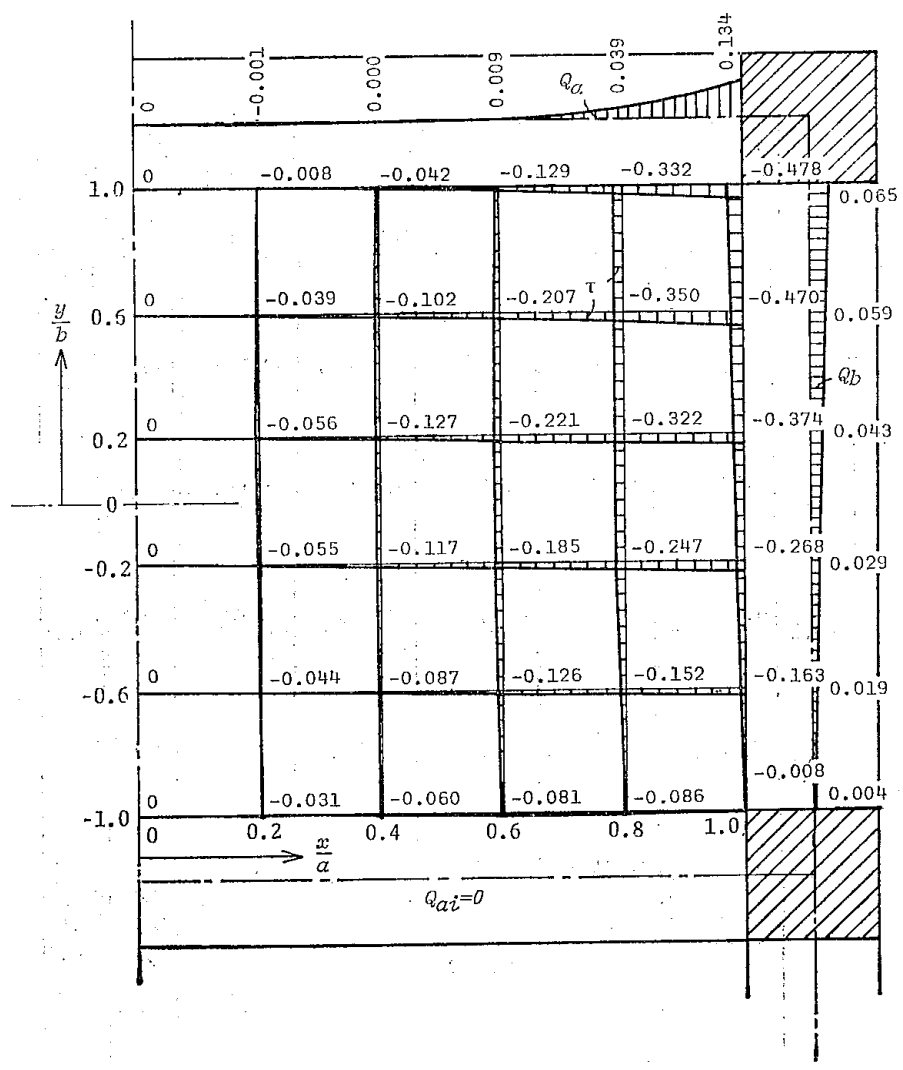

Fig. 7 The shearing unit stress $\tau$ in the wall (unit: $P / t h$ ) and the shearing force $Q$ on a cross section of the frame (unit : $P$ ) [Type II] 


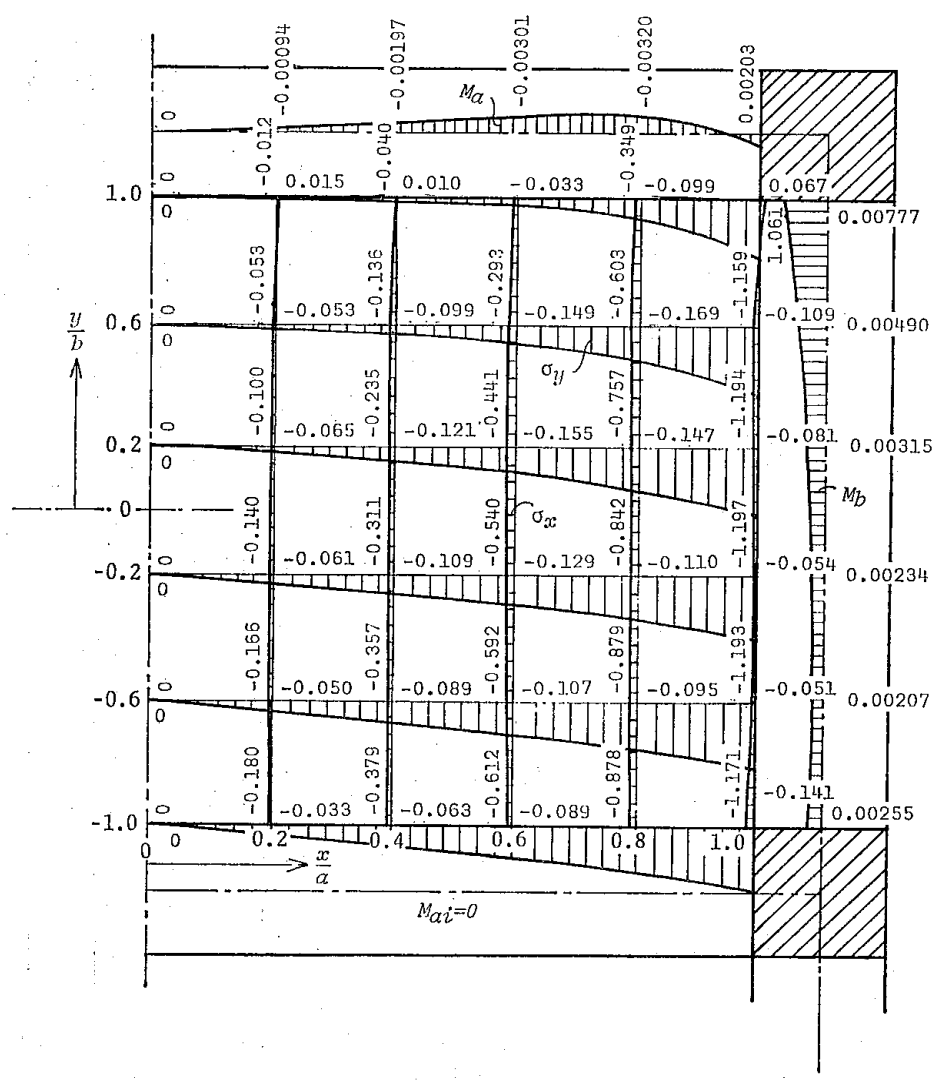

Fig. 8 The normal stresses $\sigma_{x}$ and $\sigma_{y}$ in the wall (unit :P/th) and the bending moment $M$ in the frame (unit:Ph) [Type III]

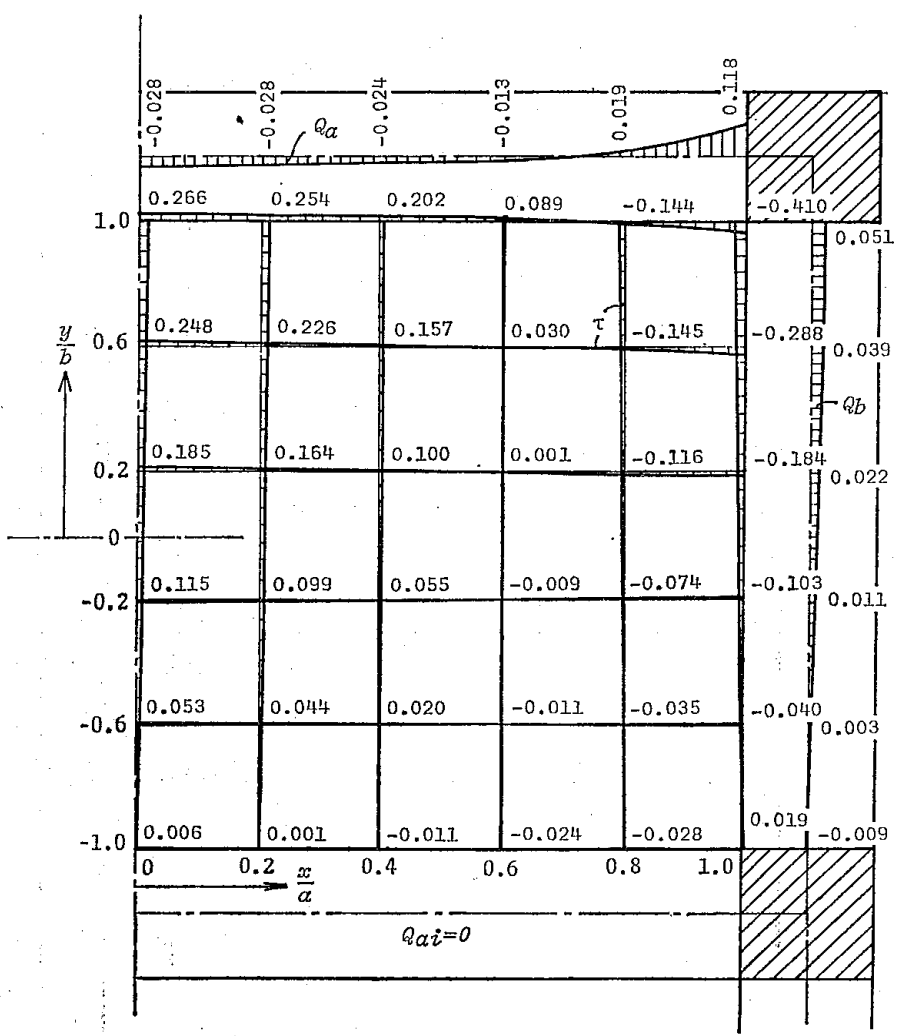

Fig. 9 The shearing unitstress $\tau$ in the wall (unit: $P / t h$ ) and the shearing force $Q$ on a cross section of the frame (unit : P) [Type III] 
quakes, the plane at the boundary between the intermediate member and wall remains to plane approximately (See Fig. 8).

By applying the unit fundamental components of Types II and III (See Fig. 10) to the duplex shear wall, the elements of the partitioned matrices of Types III and III. of the fundamental flexibility matrix of the duplex shear wall ${ }^{1}$ can be given as the nodal displacements of the node $i$ or the node $k$ (See Fig. 11) and are mentioned in Eqs. 18 and 19 for the three numbers $\left(r_{m(o)}=r_{m(e)}=r_{n(o)}=r_{n(e)}=5,15\right.$, 25) of the terms of the serial stress functions.

Here, the nodal external forces and nodal displacements in the positive $x$ - and $y$-directions mentioned in Fig. 12 have positive signs. The clockwise nodal moments and clockwise nodal rotational angles have positive signs.

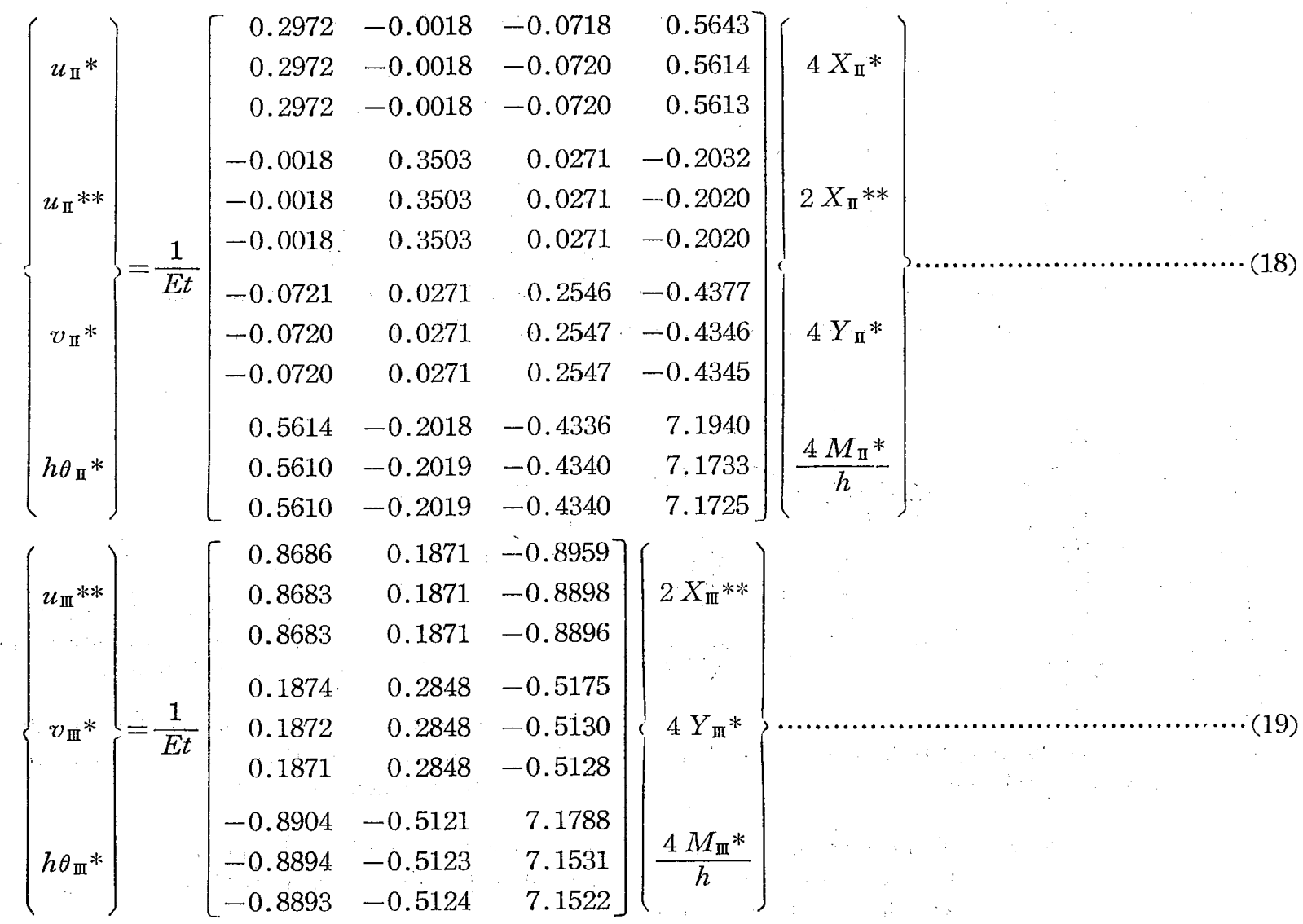

where

The values in the top row of each element are derived by taking $r_{m(o)}=r_{m(e)}=r_{n(o)}=r_{n(e)}=5$.

The values in the middle row of each element are derived by taking $r_{m(o)}=r_{m(e)}=r_{n(o)}=r_{n(e)}=15$.

The values in the bottom row of each element are derived by taking $r_{m(\theta)}=r_{m(e)}=r_{n(o)}=r_{n(e)}=25$. $4 X_{\mathrm{II}}^{*}, 2 X_{\mathrm{II}}{ }^{* *}, 4 Y_{\mathrm{II}}{ }^{*}, 4 M_{\mathrm{II}}^{*}, 2 X_{\mathrm{II}}^{* *}, 4 Y_{\mathrm{III}}{ }^{*}, 4 M_{\mathrm{II}}^{*}=$ Representative components of the fundamental components of Types II and III of the nodal external forces, which are given as the total of the absolute values of the independent fundamental components and take the sign of the components of the node $i$ (* is attached) or the node $k$ (** is attached) (See Fig. 10)

$u_{\mathrm{I}}{ }^{*}, u_{\mathrm{I}} * *, v_{\mathrm{\Pi}}^{*}, \theta_{\mathrm{I}} *, u_{\mathrm{II}^{* *}}, v_{\mathrm{II}}^{*}, \theta_{\mathrm{II}}^{*}=$ Representative components of the fundamental components Types II and III of the nodal displacements which are the fundamental components of the node $i$ or the node $k$ (See Fig. 11)

When the serial stress functions with twenty-five terms are applied, the absolute values of errors, with respect to the symmetry of the elements of the partitioned fundamental flexibility matrices of Types II and III, are less than $0.0005 / E t(0.115 \%)$ and $0.0004 / E t(0.078 \%)$, respectively. This accuracy for symmetry indicates the reliability of this analysis.

The values of the elements of the partitioned fundamental flexibility matrices derived by using the serial stress function with fifteen terms are nearly equal to those values derived by using the serial stress 

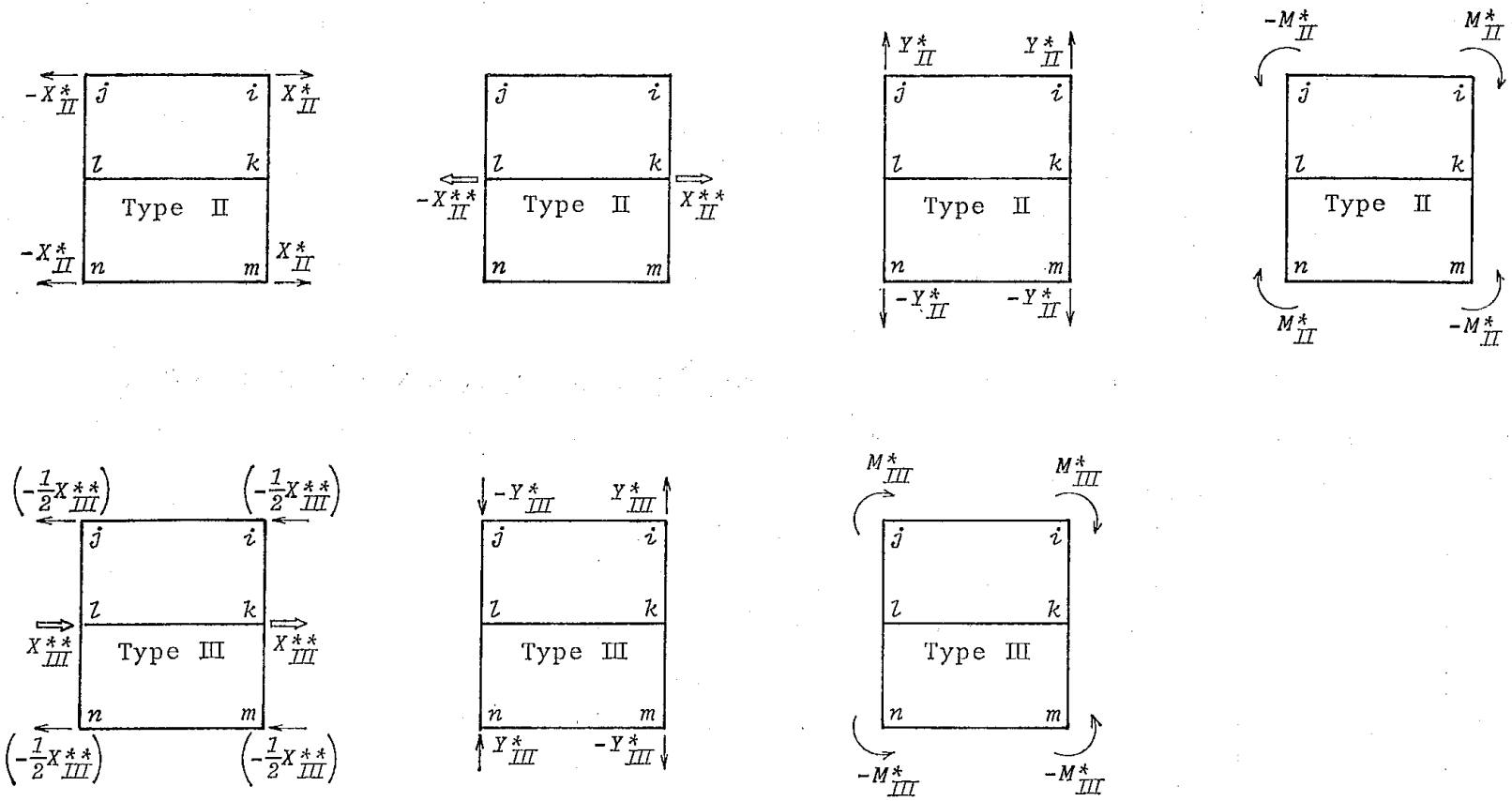

Note: The vaues in parentheses are treated as the dependent fundamental components

Fig. 10 Fundamental components Types II and III of nodal external forces

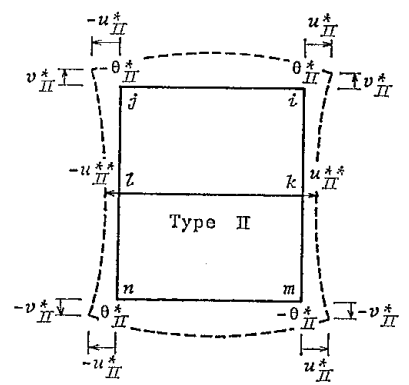

Fig. 11 Fundamental components Types II and III of nodal displacements

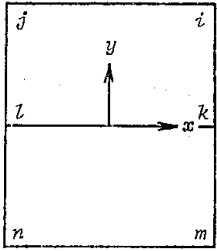

Note:

The $i, j, k, l, m$ and $n$ are the symbols of the nodes of thboundary frame of a duplex framed shear wall.

Fig. 12 Positive directions $x$ and $y$ of the fundamental components of nodal external forces and nodal displacements

Table 2 The comparison of the axial forces and the vertical displacements for the upper column by the conventional equivalent strut method and the analytical method

\begin{tabular}{l|c|c|c}
\hline \multirow{2}{*}{ External force } & \multicolumn{2}{|c|}{ Axial force(unit:P) } & Vertical displacement of the top \\
\cline { 2 - 3 } & top & bottom & the upper column (unit:P/Et) \\
\hline \multirow{3}{*}{ Type II } & 0.866 & 0.608 & 1.019 \\
& 0.805 & 0.805 & 1.011 \\
& $7 \%$ & $32 \%$ & $1 \%$ \\
\hline \multirow{3}{*}{ Type III } & 0.882 & 0.748 & 1.139 \\
& 1.000 & 1.000 & 1.279 \\
& $13^{\circ}$ & $34 \%$ & $12 \%$ \\
\hline
\end{tabular}

The values in the top row are derived by the analytical method.

The values in the middle row are derived by the conventional equivalent strut method.

The values in the bottom row are the error for the values by the analytical method.

functions with twenty-five terms.

Therefore, these values converge well enough by adopting the serial stress functions.with fifteen terms.

The axial forces in the column of the boundary frame determined by the conventional equivalent strut method and analytical method mentioned above are shown in Table 2 for the external forces of Type II and III (See Fig. 5).

The maximum error for the axial force is $34 \%$ at the bottom of the upper column. The maximum 
error for the vertical displacement at the top of the upper column is $12 \%$ for Type III.

Therefore, the conventional equivalent strut method cannot be used to determine the axial force of the column of the boundary frame or the vertical displacement of the top of the upper column of the boundary frame of the duplex framed shear wall.

In the equivalent frame of the conventional equivalent strut method, the axial and flexural rigidities of the heams are assumed to be infinite.

The columns are hinged to those beams, and the struts are hinged to the frame diagonally (See Fig. 13).

Here, the cross-sectional area of the struts in the equivalent
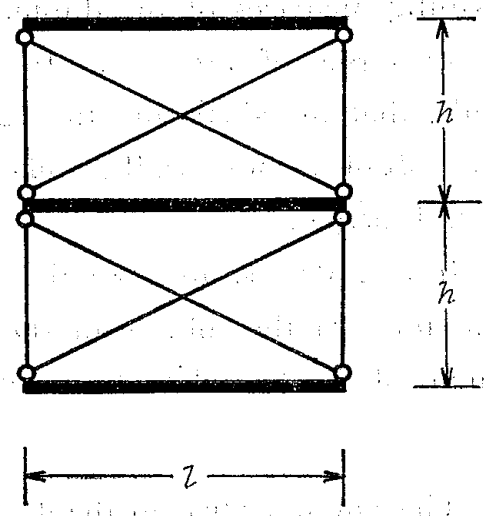

Fig. 13 The conventional equivalent frame with struts frame is determined by assuming that the shearing rigidity of the wall, where the horizontal crosssectional area is $l t$, is equal to that of the equivalent frame, and is given by Eq. 20.

And the cross-sectional area of the columns in the equivalent frame is determined by assuming that flexural rigidity of the horizontal I-shaped cross-section of the shear wall is equal to the flexural rigidity of the equivalent frame with struts, and is given by Eq. 21 .

$$
A_{b}=\frac{G}{E} \cdot \frac{t\left(h^{2}+l^{2}\right)^{1.5}}{2 \kappa l h}
$$

where : $A_{b}=$ Cross-sectional area of the struts in the equivalent frame

$h=$ Distance from center to center of the edge beam and intermediate beam of the duplex shear wall

$l=$ Distance from center to center of the edge columns of the duplex shear wall

$\kappa=$ Shear factor for shearing deformation

$$
A_{c}=\frac{4}{l^{2}} I_{w c}+A_{w c}+\frac{t l^{\prime 3}}{6 l^{2}}
$$

where $\quad A_{c}=$ Cross-sectional area of the columns in the equivalent frame

$I_{w c}=$ Geometrical moment of inertia of the edge columns of the duplex shear wall

$A_{w c}=$ Cross-sectional area of the edge columns of the duplex shear wall

$l^{\prime}=$ Clear span of the boundary frame

The numerical results were computed by the digital computer (FACOM M-190, 15 effectives) of the Kyushu University Computer Center.

\section{Conclusions}

Following the analysis of single framed shear walls, exact elastic analysis method of duplex shear walls symmetric with regard to both the longitudinal and transversal center lines was investigated by using Airy's stress function.

The elastic analysis of duplex shear walls whose shapes are symmetric with respect to the longitudinal and transversal center lines subjected to antisymmetrical loads with respect to the axes of the intermediate members of their frames can be induced by revising the boundary conditions and analytical method of the left edge columns of one-bay-one-story framed shear walls whose edge beams have the same sections but whose edge columns have different sections so as to correspond to the boundary conditions and analytical method of the intermediate beams of the duplex framed shear wall.

Thus, the stresses in the walls, beams and columns which cannot be given by the equivalent strut method can be obtained by this analysis.

From these numerical results the following things are observed.

In the case when the duplex shear wall is subjected to the nodal forces of Type III, which are considered to be one of the main components of external forces operative during earthquakes, the plane at the boudary between the intermediate member and wall remains to plane approximately.

It was numerically investigated how the values of the elements of the partitioned fundamental 
flexibility matrices of the duplex shear walls of Type II and III converge with the increse in the number of terms of the stress function when this analytical method is applied. It is pointed out, as a result, that in calculating the values of the elements of the partitioned fundamental flexibility matrices of the duplex shear walls, sufficient accuracy is obtained by taking about fifteen terms of the serial stress function.

It was also pointed out that the conventional strut method cannot be used to determine precisely the axial force of the column of the boundary frame or the vertical displacement of the top of the upper column of the boundary frame in the duplex framed shear wall.

\section{ACKNOWLEDGEMENT}

The authors wish to thank Miss Kiyoko Furuta who typed the manuscript of this paper.

\section{REFERENCES}

1) M. Tomii and T. Yamakawa, "Stiffness Matrix of Two-Story or Two-Bay Duplex Framed Shear Walls," Transactions of the Architectural Institute of Japan (T.A.I.J.), No. 284, Oct. 1979

2) M. Tomii, M. Inoue and K. Sawada, "Elastic Analysis of. Framed Shear Walls Whose Right and Left Columns Have Different Sections, Part I-The Case When the Shear Walls Are Subjected to Antisymmetrical Loads with respect to Their Transversal Center Lines-," Abstracts of Annual Convension of Architectural Institute of Japan; Sep. 1978 (in Japanese)

3) M. Tomii and M. Inoue, "Elastic Analysis of Framed Shear Walls Whose Right and Left Columns Have Different Sections, Part II-The Case When the Shear Walls Are Subjected to Symmetrical Loads with respect to Their Transversal Center Lines-., Abstracts of Annual Convention of Architectural Institute of Japan, Sep. 1978 (in Japanese)

4) M. Tomii and H. Hiraishi, "Elastic Analysis of Framed Shear Walls by Considering : Shearing Deformation of the Beams and Columns of Their Boundary Frames, Part I, Shearing Deformation of the Beams and Columns of the Frames," T.A.I.J., No. 273, Nov. 1978

5) M. Tomii, N. Sato M. Inoue, "Elastic Analysis of Two-Story or Two-Bay Duplex Framed Shear Walls Subjected to Antisymmetrical Loads with respect to the Axes of the Intermediate Members of Their Frames", T.A.I.J., No. 297, Nov. 1980 


\section{付帯ラーメンの中間部材の材軸に関して 対称な外力を受ける 2 連耐震壁の弾性解析（梗概）}

$\begin{array}{lllll}\text { 正会員 富 } & \text { 井 政 } & \text { 英** } \\ \text { 正会員 井 } & \text { 上 } & \text { 正 } & \text { 支** } \\ \text { 正会員 } & \text { 栗 } & \text { 山 } & \text { 公 } & \text { 典**** }\end{array}$

\section{1. 序}

本論の目的は，慣用のビーム法やブレース置換法では 求めることができない 2 連而震壁の壁板内，付帯ラーメ ン部材のそれぞれの弾性応力や変形の解析解をはじめ, 多連而震壁の付帯ラーメンの節点に関する剛性マトリッ クスを求めるための基本的要素となる，中心軸に関し， 左右，上下とも対称な形状の 2 連耐震壁の基本たわみ性 マトリックスの 4 個の部分マトリックスのらちの 2 個の 部分マトリックスの解析解などを求めることにある。こ のよらな 2 連耐震壁の基本たわみ性マトリックスと剛性 マトリックスの関係は，既に富井，山川により発表され ている゙”。また，本解析および慣用のブレース置換法に より算出された 2 連耐震壁の柱の軸力および柱頭の鉛直 変位の数值計算結果を比較し，慣用のブレース置換法の 欠陷を指摘した。

本解析は，中心䡋に関し上下対称で左右柱断面の異な る単独耐震壁の弹性解析 ${ }^{2,3)}$ 亿扝いて, 左柱の境界条件 と解析法を 2 連耐震壁の中間ばりの境界条件と解析法に 修正するような方法を採用した。

本解析では， 2 連耐震壁に作用する一般的な外力に関 し，付帯ラーメンの中間部材の材軸に関して対称な外力 成分をとり上げ，この外力成分をさらに 2 通りの基本外 力成分に分解し，それぞれの基本外力成分を次のよ5に 呼び, 逆対称, 対称条件を考慮して， 2 連耐震壁の 4 分 の 1 部分（単位の耐震壁の $x \geqq 0$ の部分）について解 析を行なった (図 1 参照)。

II型の外力 : 中心軸に関し, 左右，上下とも対称な外力 III型の外力：中心軸に関し，左右逆対称，上下対称な外

力

解析には次の仮定を用いた。すなわち

1. 壁板は 2 次元弾性体とする。

2. 壁板と付帯ラーメン部材は密着固定している。

3. 付帯ラーメン部材の接合部（図 1 の斜線部分）は

* 九州大学 教授・工博

***大分大学 講師 $・$ 工修

**** 福岡県 技師・工修

（昭和 55 年 3 月 7 日本稿受理・討論期限昭和 56 年 4 月末日）
剛域とみなす。

4. 付帯ラーメン部材には, せん断変形を考慮した初 等曲げ理論4 を適用する。

II型の外力は任意に与えられるが，亚型の外力は任意 に与完られず，水平方向の力のつりあい式である 1 式を 満足しなければならない。ここで， $x$ 拉よび $y$ 方向の外 力ならびに時計迴りのモーメントを正とする。

\section{2. エアリーの応力関数}

II型抒よびIII型の外力に対して, 級数型応力関数と代 数型応力関数を各々 2,3 式のように選んだ。これらの 応力関数は 4 式の適合条件を満足する。

3. 壁板内の応力度, ひずみ度, 変位

$x, y$ 軸に平行な垂值応力度 $\sigma_{x}, \sigma_{y}$ およよ゙せん断応力 度 $\tau, x, y$ 軸に平行な垂直ひずみ度 $\varepsilon_{x}, \varepsilon_{y}$ おるよびせん 断ひずみ度 $r, x, y$ 方向の変位 $u, v$ は，それぞれ，5， $6,7,8,9,10,11,12$ 式加求められる。

4. 付帯ラーメン部材の応力, 変位など

2 連耐震壁の外ばりと柱の応力, ひずみ度, 变位ば, 富井, 平石により示された単独耐震壁の柱とはりの応 力，ひずみ度，変位の式4)を用いて表わすことができる が，中間ばりに関しては，各式を修正する必要がある。

中間ばりの微小部分 $D_{a i} \times d x$ に作用する応力を図 3 に示す。

III型亚型の外力が作用する場合は，中間ばりにはせん 断変形がなく，曲げモーメントとせん断力は零である。 中間ばりの軸力 $N_{a i}$ は 15 式により与えられる。

III型の外力が作用寸る場合, 軸力 $N_{a i}$ が $y$ 軸に関し て逆対称であり， 15 式の積分定数は零となる。II型の 外力に対しては，この積分定数は未知積分定数となり, 表 1 に示す連立方程式を解くことによって，他の未知係 数や未知積分定数とともに決定される。

\section{5. 末知係数および末知積分定数を決める条件式}

2,3 式に示した応力関数 ${ }_{\text {II }} F$ および 桂 $^{2}$ に含まれ る末知倸数と諸式の誘導過程で生じる未知積分定数を決 定する条件式（連立方程式）を表1亿示す。条件式流， 壁板と外ばり抒よび右柱の境界上の垂直灾力のつりあい 条件式, 壁板と付帯ラーメン部材の境界上の境界線方向 
ひずみ度の連続条件式, 壁板と中間ばりの境界での鉛直 変位の連続条件式, 付帯ラーメン部材の接合部が唰域で あるための条件式，付帯ラーメン部材の接合部における 軸方向力およびモーメントのつりあい条件式からなって いる。条件式の数は，正型の外力に関しては $4 r_{m(e)}+2$ $r_{n(o)}+2 r_{n(e)}+14$ 個, III型の外力に関しては $4 r_{m(o)}+$ $2 r_{n(o)}+2 r_{n(e)}+10$ 個である。これらの条件式の個数は， II型掠よびIII型のそれぞれの外力に関して， $F$ および III $F$ の未知係数ならびに諸式の誘導過程に招ける未知積 分定数の総数に等しい。これ小り, 表 1 に示寸斬立方程 式を解くことができる。

\section{6. 数值計算例}

日本建築学会鉄筋コンクリー小構造計算規準・同解説 の設計例の単独耐震壁と同一形状の単位耐震壁からな る, 図 4 亿示す 2 層耐震壁に刘し，数值計算を行なった。 図 5 に示すような節点外力を受ける2 層耐震壁の壁板 の垂直店力度 $\sigma_{x}, \sigma_{y}$, せん断応力度 $\tau$, 付带ラーメン部 材の軸力 $N$, 曲げモーメント $M$ 执よびせ儿断力 $Q$ を， 図6 9 亿示した。ここで, ポアソン比レは $1 / 6$ と仮定 した。

図 5 (a) に示すII型の敛直節点外力成分が作用する場 合の応力状態 (図一 $6 ， 7$ 参照) と既報 ${ }^{5}$ ，で報告した IV 型の鉛值節点外力成分が作用する場合の応力状態とを重 权合せることによって, 鉛直荷重時の応力状態を得るこ とができる。また，図 5 (b) に示すような水平何重時の 成分である亚型の節点外力が作用する場合, 壁板内の中 間ばりとの境界付近では平面保持に近い応力状態（図 8 参照）となっていることがわかる。

図 10 に示す単位の基本節点外力を与えると, 図 11 に

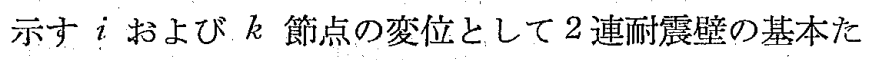
わタ性マトリックスの川型抒よびIII型の部分マトリック 入の各要素が得られる ${ }^{1)}$ 。級数型応力関数の項数 $\left(r_{m(o)}\right.$ $\left.=r_{m(e)}=r_{n(o)}=r_{n(e)}\right)$ を 5 項, 15 項および 25 項しして 計算した場合のII型抒よび开型の部分基本たわ夕性マ下 リックスを 18,19 式に示す。

ここで，節点外力および節点変位は，図 12 に示す $x$, $y$ 軸の方向を正とし, 節点モーメントおよび節点回転角 は，時計迴りの方向を正とする。

25 項の 級数型応力関数を用いた場合, II型およびIII 型の部分基本たわみ性マトリッタスの対称性に関する諨 差の絶対值は，それぞれ 0.0005/Et (0.115\%) および $0.0004 / E t(0.078 \%)$ 以下である。この対称性の正確さ が本解析の信頼性を示している。

また，これらのマトリックスの各要素の值は 15 項の 場合と 25 項の場合, その差が極めて小さい。これよ $\eta, 15$ 項の級数型応力関数を用いれば，基本たわみ性 マトリックスの各要素の值は十分収㪘すると思われる。
本解析により得られた付帯ラーメン部材の柱の軸力格 よび上部柱の柱頭の鉛直方向変位を，慣用のブレース置 換法により得られたものとともに表 2 に示す。な执外力 は図 5 に示す型拉よび亚型外力である。表 2 上り，上 部柱の柱脚部分の軸力で最大 $34 \%$ ，上部柱の柱頭の鉛 直変位で最大 $12 \%$ の䛊差を生じている。ゅ流、慣用 のブレース置掺法は 2 連耐震壁の付带ラーメン柱の軸力 および上部柱の柱頭の鉛直変位の算出に烓，㬰用設計上 使用することができない。

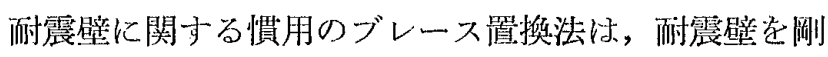
なはりとこれにピン接合された柱で構成された骨組に雨 端ピンの筋違を両対角線に挿入した筋逞入骨組に置換す る方法である (図 13 参照)。ここで筋違の断面積は, 筋 堂入り骨組のせ九断剛性が, 耐震壁の壁板部分（水平断 面積 $l$ ）のせん断剛性と等しくなるように 20 式で与え られ，柱の断面積は，觔違入骨組の曲げ岡性と耐震壁の I 型水平断面の曲げ岡性が等しくなるように 21 式で与. えられる。

数值計算には,九州大学大型計算機七ンター(FACOM M-190 ; 有效桁数 15) を用いた。

\section{7. 結 論}

単独耐震壁に引続き, 左右, 上下とも対称な形状の 2 連耐震壁に対しても,フーリエ級数型の応力関数を使っ た悠密な弾性解析法の研究を行った。その結果, このよ らな 2 連耐震壁に，その付帯ラーメンの中閒部材の材軸 に関して対称な外力が作用する場合の解析は, 既に著者 らが発表した「中心軸に関し上下刘称で左右柱断面の異

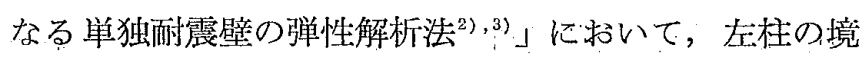
界条件と解析法を 2 連耐震壁の中間ぼりの境界条件と解 析法に置换するよらな修正を行ならことによって可能と なることを明らかにした。

本解析による壁板，付帯ラーメン部材の応力の数值計 算例を示した。この解析例では, 水平荷重時の成分であ るIII型の節点外力が作用する場合, 壁板内の中間ばりと の境界付近では平面保持に近い応力状態となっているこ とを明らかにした。

また， 2 連耐震壁を含む有壁ラーメンのマトリックス 構造解析に必要な 2 連耐震壁の剛性マトリックスをこの 基本たわ为性マトリックスから求める゙ ため，II型およ びIII型の部分基本たわみ性マトリックスの要素を算定す る場合には, 忘力関数の項数を 15 項もとれば, 十分な 精度が得られることを指摘した。

慣用のブレース置撸法は 2 連耐震壁の付寡ラーメン柱 の軸力や上部柱の柱頭の鉛直变位の算出には奏用設計上 使用することはできないことを明らかにした。

注：文中の式，図表扝よび引用文献は英論文を参照されたい。 